The Chittagong Univ. J. Sci. 41(1) : 148-177, 2019

DOI: https://doi.org/10.3329/cujs.v41i1.51921

\title{
Contextualization of Forest Governance for Implementation of REDD+ in Bangladesh
}

\author{
Md. Danesh Miah* and Gazi Azizul Islam \\ Institute of Forestry \& Environmental Sciences, University of Chittagong, \\ Chittagong 4331, Bangladesh \\ *Corresponding author; E-mail: danesh@cu.ac.bd; dansmiah@gmail.com
}

\begin{abstract}
Poor governance accelerates the deforestation and forest degradation through corruption in Bangladesh due to the enhancement of prevalent activities such as excessive collection of forests products, trafficking of logs out of reserve forests, land grabs by powerful actors, illegal encroachment of forests, etc. The study was conducted with a view to assessing the present scenario of the forest governance system based on five UN principles in Bangladesh which will be the driving force to the successful implementation of the REDD+. The study was conducted in Rangamati, Madhupur, and Sreemangal, through focus group discussion, key informants interview, and an online survey. The study shows that lack of transparency, accountability, and integrity is one of the main underlying drivers of deforestation and forest degradation. Restriction to accessing reports on fiscal activities, lack of laws and regulation concerning to public funds, lack of independent institution, ineffective monitoring and testing systems, and inadequate detection, investigation, and prosecution practices, etc. enhance the corruption in the forestry sector and the hindrances of effective REDD+ implementation in Bangladesh. The study suggested taking legal protection, engaging civil society and
\end{abstract}


improving the organizational structures of the forest department to check the corruption in the forestry sector of Bangladesh.

Keywords: Corruption; Fiscal activities; Laws and regulations; Public accounting; Procurement policy.

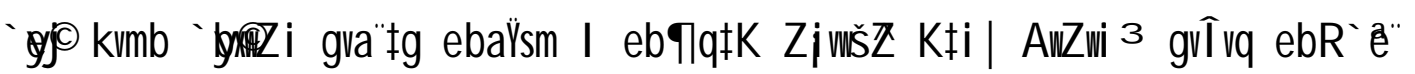

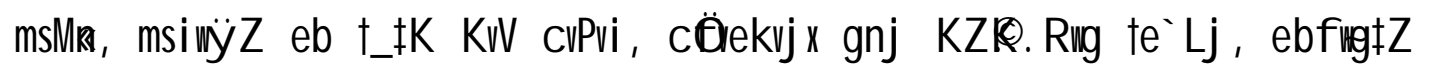

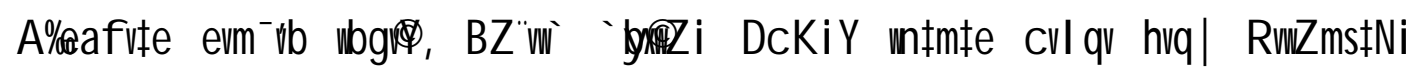

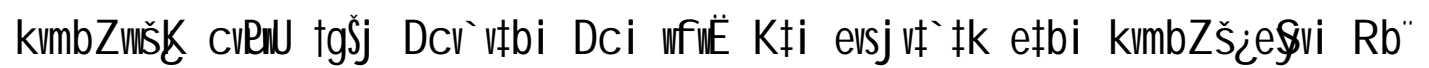

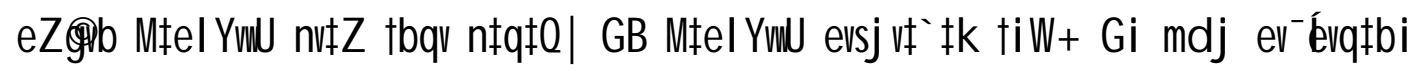

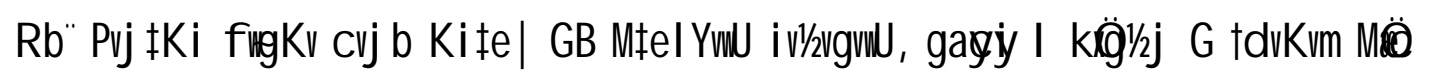

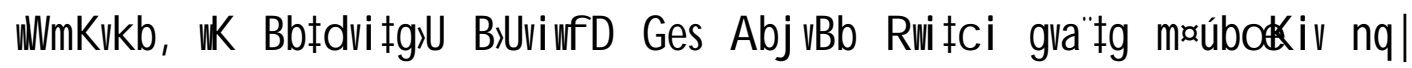

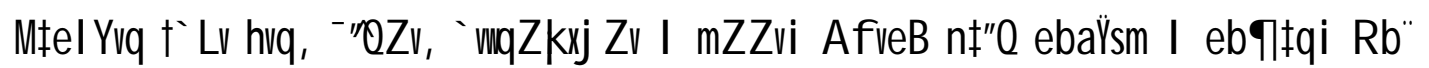

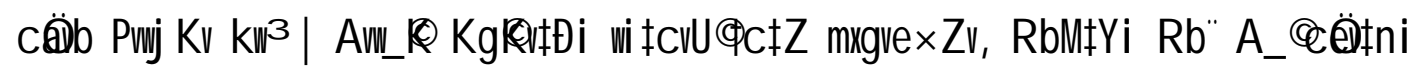

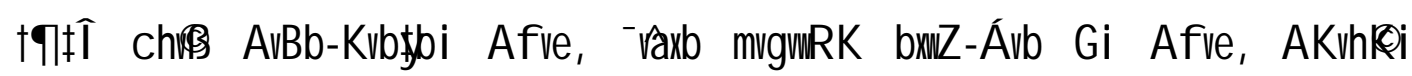
যাচাইকরণ, পরীক্ষণতন্ত, ও তদন্ত প্রক্রিয়া বনবিভা\$M ‘

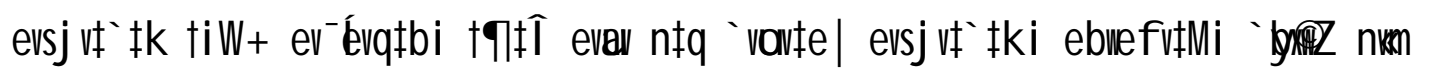

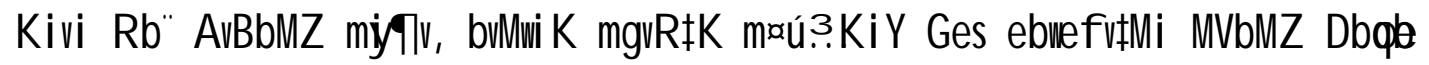
Ki \#di Rb“ eZgb Mel Yudci igk $(9)$ q

\section{Introduction}


Weak forest governance accelerates deforestation, biodiversity loss, damage of ecosystems, land erosion, loss of revenues, destruction of vulnerable and protected forests, deterioration of ethical values for law and chaos in society [1]. Around \$20 billion per year is lost from illegal cutting in public land and annually about US \$5 billion is lost due to corruption for uncontrolled taxes and royalties on timber harvest [2]. Failure of forest governance puts risk at poor and forest dependent people while about 1.6 billion people all around the world depend on forest for their livelihoods [2,3]. Annually around US\$20 billion investments are expected to flow in forestry sector through REDD+ and transparent, accountable forest government can ensure the proper benefit sharing to the stakeholder [4]. Due to the corruption, Bangladesh has accounted for $\mathrm{Tk} 540$ billion in three sectors (privatization of industries, banking and insurance, and upazilla parishad); Government's revenue lost is about Tk 12.5 million per year in the Sundarbans for extra Nypa leaves collection and the forest official embezzles annually Tk 62.5 million from the Bawalis in the Sundarbans area $[5,6]$.

About $17 \%$ of global anthropogenic emissions of greenhouse gasses are occurred from forest degradation and deforestation in the tropical country [7]. The 15th Conference of the Parties (COP-15) under the auspices of the United Nations Framework Convention on Climate Change (UNFCCC) in Copenhagen adopted REDD+ (Reducing Emissions from Deforestation and Forest Degradation and supporting the role of conservation, sustainable management of forests and enhancement of forest carbon stocks in developing countries) as priority measures to reduce forestry-based carbon emissions through a regulated market $[7,8]$. 
REDD+ provides financial incentives for local actors to halt deforestation or improve carbon stocks through funding by Annex I parties and ensures a potential source of new revenues for many developing countries $[9,10]$.

The international carbon market will ensure US\$2 billion to US\$10 billion of finance for protecting forest through REDD+ [11]. But the main challenge is the proper distribution of benefits from community-based REDD+. It needs transparency, accountability, awareness of property rights, proper democratic structure, local people's involvement in decision making and addressing their livelihood issues $[12,13]$. While outlining the principles of good governance of UN in the $21^{\text {st }}$ Century, the Institute of Governance discussed five good governance principles, i.e., Legitimacy and Voice (Participation, Consensus orientation), Direction (Strategic vision), Performance (Responsiveness, Effectiveness and Efficiency), Accountability (Accountability, Transparency) and Fairness (Equity, Rule of law) [14]. These principles are claimed to have universal recognition to be the measuring stick of governance. At present, Bangladesh is working with UNREDD program to get funds and in 2012 Bangladesh prepared a draft national REDD+ roadmap emphasizing the development of national guidelines, extension workers and establishing an independent grievance mechanism for forestry and environmental issues $[15,16]$. The factors which influence the deforestation and forest degradation in developing countries are economic development and growth, population densities, climate events, governance system, law enforcement, land conversion for agriculture, cash crops and illegal logging and state forest 
encroachment $[17,18]$. Weak financial governance accelerates the corruption and fraud in reforestation and forest restoration program also [19].

REDD+ scheme protects the threatened biodiversity in the carbon-rich tropical countries especially in tropical forest harboring greater than half of the worlds threatened species and at least two-thirds of all known terrestrial species [20-22]. REDD+ for forest conservation will ensure the biodiversity conservation and $12 \%$ of the world's forest for biodiversity conservation store $289 \mathrm{Gt}$ of carbon in their biomass alone and REDD+ finance leads to the greater reductions in deforestation, greater climate change mitigation and greater provisions of biodiversity [4,23-26].

Tropical forest ecosystems ensure food security for hundreds of millions of people and about 1.6 billion people all around the world depend on the forest for fuelwood, wild foods, household incomes and employment [3,27-31]. The tribal, ethnic group and poor people in India and Bangladesh depends on the forest for food security and livelihood supports [32,33]. In spite of possibilities of getting carbon credits fromthe forestry sector through REDD+ and the conservation of forests in Bangladesh, the knowledge pool lacks the understanding of contextualization of REDD+ and forest governance to ensure the Legitimacy and Voice, Direction, Performance, Accountability, and Fairness [14]. So, this study was conducted with the objectives of finding out factors of corruption accelerating deforestation and forest degradation; finding out flaws of organizations managing REDD+ in Bangladesh; finding out the effectiveness of monitoring and testing systems for public offices, and finding out the effectiveness of present practices to 
check corruption. This study will be helpful to take measures against corruption and the proper implementation of the REDD+ program in Bangladesh.

\section{Materials and Methods}

To realize the objectives of the study, Five Focus Group Discussion (FGD) and 15 Key Informant's Interview (KII) were performed in each of Rangamati, Madhupur, and Sreemangal. The online survey was conducted using the 'Survey Monkey' professional version [34]. In an online survey, 200 personnel were requested to participate in the survey. The online survey form was sent to the respondents who were relevant with the forestry sector, REDD+, and anti-corruption activities. However, the 'Survey Monkey' received 68 respondents (34\%) only. Among the received survey, $88 \%$ were male and $12 \%$ were female. In the online survey, the highest numbers of the respondents (47\%) were in the age group 20 and 35, while the lowest numbers of respondents (2\%) were in both the age groups below 20 and 51 to 65 . About $46 \%$ of respondents were in the age group 36 to 60 .

About 12 work/occupational class respondents participated in the online survey. They were from Local Government, Business Sector, International Institutions/Groups, Non-Government Organization, Indigenous Peoples' Organization, Academic Institution, Forest Department, Civil Society, Government Administration, Sawmill, Furniture industry, Anti-corruption agency/enforcement bodies. The maximum numbers of respondents (16\%) were from international Institutions/ groups while the minimum numbers of respondents (1\%) were from local government offices (Figure 1). 
154 Contextualization of Forest Governance for Implementation of REDD+ in Bangladesh

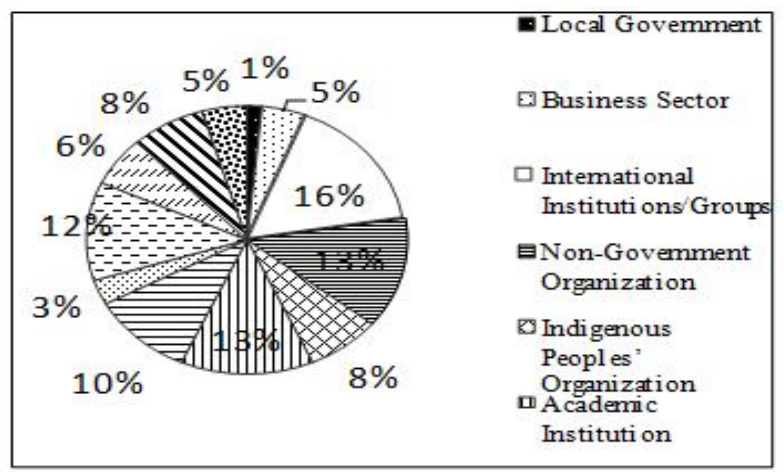

Figure 1.Percentage distribution of the respondents' occupation in the online survey for assessing possible corruption risks to successful implementation of REDD+ in Bangladesh.

In the online survey, about $55 \%$ of respondents had the work experiences in Bangladesh lifelong and about $26 \%$ had over 10 years experiences. About $5 \%$ of respondents had 5 years of work experiences (Figure 2).

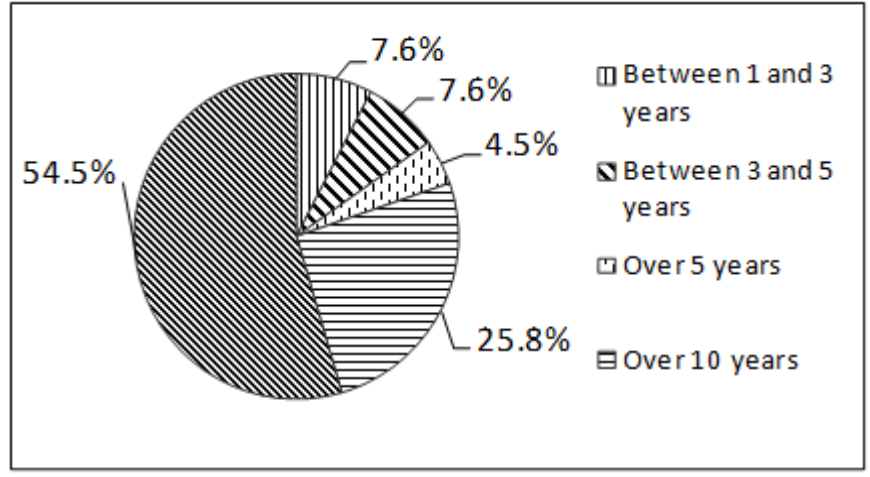

Figure 2. Percentage distribution of the respondents' work experience in the online survey for assessing possible corruption risks to successful implementation of REDD+ in Bangladesh. 
The FGD considered three groups separately, i.e., timber traders and furniture makers, sawmill owners, and forest-dependent people. The members of a group were in a range of $20-30^{1}$. The KII considered the local journalist, academician, leader of the ethnic community, lawyer, NGO activist, and officer of the Bangladesh Anti-Corruption Commission (ACC). The total number of the key informant interviewee was 15 in the survey. For the study, all the selection of the respondents was purposive.

\section{Results and Discussion}

\section{Knowledge level of respondents about REDD+ in Bangladesh}

In an online survey, the study found that about $36 \%$ of respondents' knowledge about REDD+ were better while about $31 \%$ of respondents were poor. Fair knowledge of respondents about REDD+ were $30 \%$ and only about $3 \%$ of respondents were expert on REDD+ in Bangladesh (Figure 3).

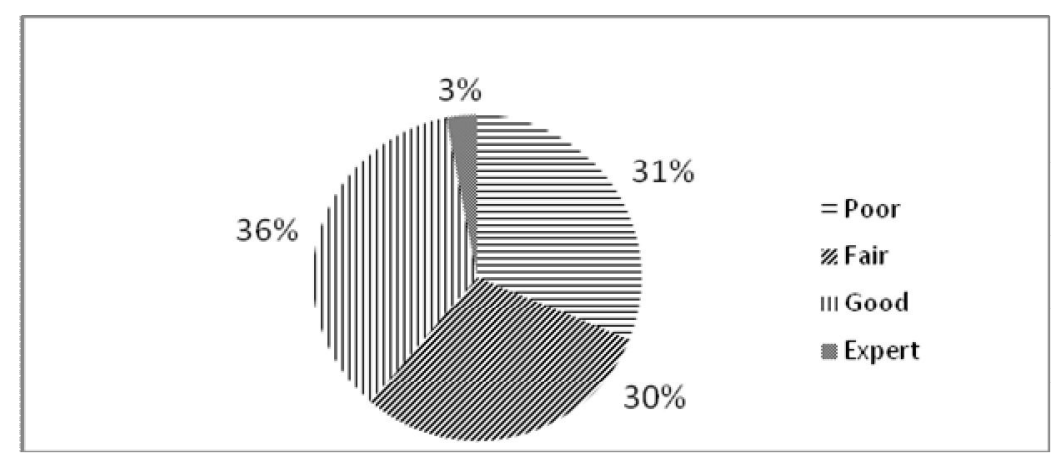

Figure 3. Knowledge level of respondents about REDD+ in Bangladesh.

\footnotetext{
${ }^{1}$ Although the optimum members of the FGD are 10, but to reduce the costs and save the time, and accommodate all three types of members in a FGD, the study accommodated the membersupto 30. But a few FGDs had more than 22 members.
} 
REDD+ is the climate change mitigation strategy introduced as an international framework to halt deforestation which will provide a largenumber of revenues to government and benefits to local stakeholders [9,10]. Proper implementation of program needs the rightpersonnel on the right places. About one-third of the respondents perceive that the knowledge on REDD+ of the country people is poor (Figure 3). It shows a need for capacity building program on REDD+ in Bangladesh.

\section{Corruption's threat to deforestation and forest degradation}

Lack of transparency, accountability,and integrity are the influencing factor of corruption in deforestation and forest degradation in Bangladesh [35]. Other underlying drivers of deforestation and forest degradation are an excessive collection of forests products, trafficking of logs out of reserve forests, forest wildlife poaching, land-grabs by powerful actors and illegal encroachment of forests [35,36]. In figure 4 , (online survey) about $38 \%$ of respondents thought that lack of transparency, accountability, and integrity were the main underlying drivers of deforestation and forest degradation. On the other hand, about $49 \%$ of respondents thought that lack of transparency, accountability, and integrity was the important driver to deforestation and forest degradation. Only $13 \%$ of respondents thought that lack of transparency, accountability, and integrity are not as important drivers of deforestation and forest degradation. 


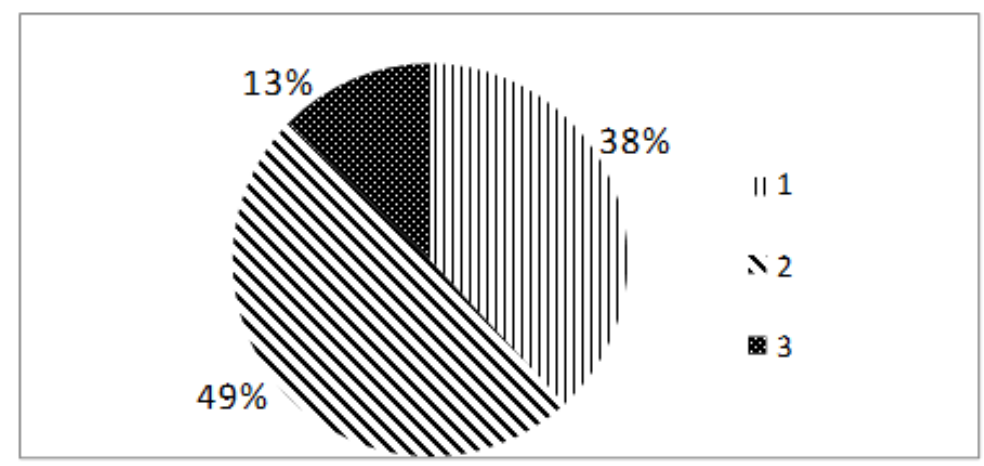

Figure 4. Perception of peoples' on corruption's threat in deforestation and forest degradation in Bangladesh.

Note: 1=Lack of transparency, accountability,and integrity is the main underlying driver of deforestation and forest degradation (38\%), 2= Lack of transparency, accountability and integrity is one important underlying driver of deforestation and forest degradation (49\%), $3=$ Lack of transparency, accountability and integrity is not as important a driver of deforestation and forest degradation as other factors, such as poverty (13\%)

The FGD and KII at Madhupur revealed that 'local thugs' forced forest officials violently to provide illegal access to extract forest resources for sawmill owners and timber traders. Forest officials take bribes around Tk 5000 per plot from local people during allocation of land. The members of parliament and other political leaders also involved illegal activities by forcing forest officials to allocate forest land for their interested persons. Forest officials also involved with illegal conversion of forest land into agricultural land.

In Sreemangal, main agents of deforestation and forest degradation were the local elite groups, political leaders, and local police. 
In Rangamati, forest officials take bribes from private loggers to extract excess timber beyond the limit of harvesting. They usually allow transport pass to the private loggers by taking extra money. They sometimes allocate forest land indiscriminately among indigenous and migrant people in lieu of bribes. These activities enhance corruption and accelerate deforestation and forest degradation. The FGDs and KIIs confirm that in Rangamati, Madhupur, and Sreemangal, there were not any transparent and accountable mechanisms to check illegal activities.

Forest officers, along with forest traders and customs officers, are involved with illegal activities such as illegal logging, timber trade/ theft, logging license and auction [1]. Some other factors of corruption in the forestry sector are also mentioned, i.e. red tape, regulations, the structure of the trade market system, traded products or provide services, monitoring, enforcement mechanisms [1]. It is noted that where transparency and political competition are high, the chance of occurring corruption is low [1].

\section{The prevalence of illegal activities}

The study shows that the prevalent illegal activities of deforestation and forest degradation in Bangladesh are an excessive collection of forests products, trafficking of logs out of reserve forests, wildlife poaching, land-grabs by powerful actors, encroachment of forests, etc. In figure 5, the ratings of land-grabs by powerful actors; an excessive collection of forests products; trafficking of logs out of reserve forests; wildlife poaching; and encroachment of forests are 3.54, 3.51, $3.35,2.82$ and 3.49 , respectively. 


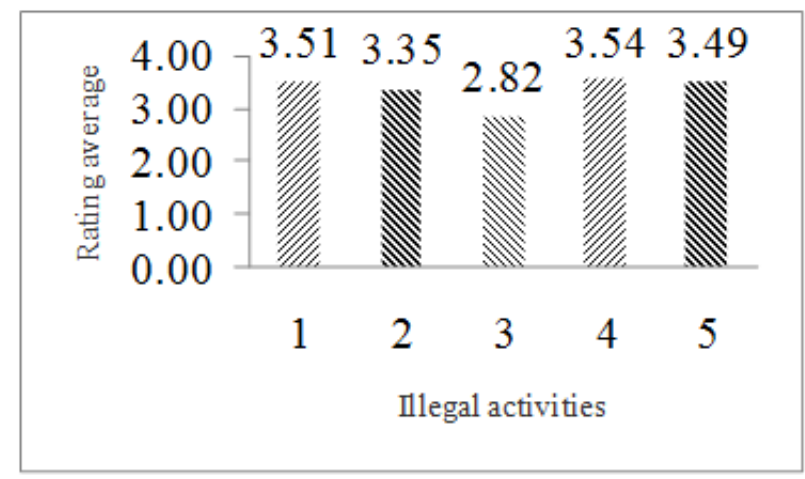

Figure 5. The prevalence of illegal activities causing deforestation and forest degradation

Note: $1=$ Excessive collection of forests products (3.51), $2=$ Trafficking of logs out of reserve forests (3.35), 3=Wildlife poaching (2.82), 4=Land-grabs by powerful actors (3.54), 5= Encroachment of forests (3.49)

The comparison with these illegal activities showed that land-grabs by powerful actors had the highest ratings of 3.54. The cause of the highest rating (3.54) of land-grabs by powerful actors is that it is done by politically involved persons and rich person in the society having enormous power and it is treated as a political issue.

Other prevalent illegal activities in Rangamati, Madhupur, and Sreemangal area were an agricultural land expansion, lack of demarcation of forest area, a large number of irrelevant forest cases, misuse of transit rules, lack of livelihood security which accelerated the rate of deforestation and forest degradation.

A study shows that the range of land-grabs is between 80 and 227 million hectares per year in a global context while in Africa, the amount of land-grab is more than 30 thousand hectares [37]. It has the social and ecological consequences while 
160 Contextualization of Forest Governance for Implementation of REDD+ in Bangladesh

widow women are the worst sufferer by the local actor with the collaboration of investor of the multinational companies for land grabbing [37]. According to Iftekhar \& Hoque [38], the main cause of deforestation and forest degradation in Bangladesh is encroachment which threats to encroach the existing natural forest within the next three decades.

\section{Accessing reports on fiscal activities}

The possibility of accessing reports on fiscal activities is limited in Bangladesh. The study showed that only $14 \%$ of people had the accessibility of reports on fiscal activities (Figure 6). The tendency of hiding reports enhances the possibility of doing illegal activities and misusing of funds.

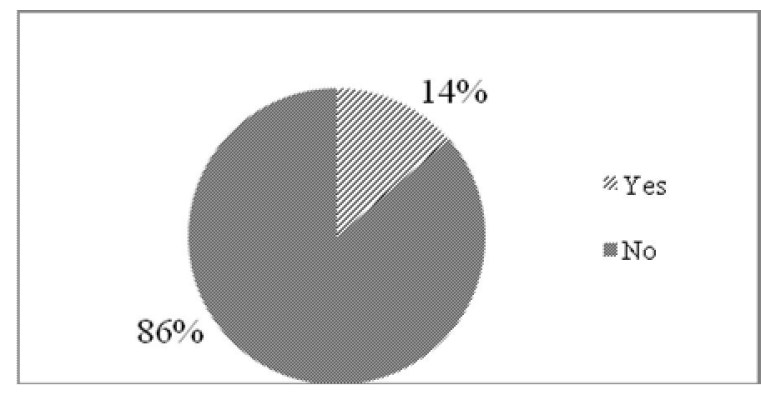

Figure 6. Present status of accessing reports on fiscal activities in Bangladesh.

In (through FGD and KII) Rangmati, Madhupur and Sreemangalthe study found that the stakeholders had no access to fiscal activities' report of the forest department. 


\section{Laws and regulations assigning authority, roles and responsibilities for the} collection, commitment and use of public funds

The study showed that only $10 \%$ of people were aware of laws and regulation assigning authority, roles and responsibilities for the collection, commitment and use of public funds in the forestry sector. About $36 \%$ of peoples were not familiar at all with those laws and regulations. On the other hand, about $35 \%$ of peoples had clear knowledge but not well understanding and about $19 \%$ of people had no idea about the laws and regulation (Figure 7).

In Rangmati, Madhupur, and Sreemangal, the FGDs and KIIs confirmed that the stakeholders had no any idea about laws and regulations concerning public funds. Lack of proper implementation of laws and regulation gives the opportunity to do illegal activities by corrupted officials, timber traders, and illegal loggers. Corruption in society deteriorates the ethical value for the law and creates social chaos which occurred in Brazil [1].

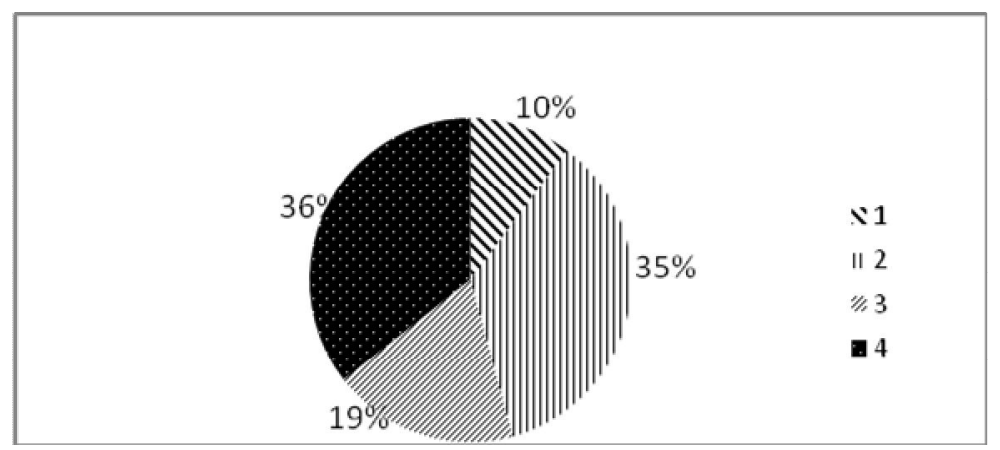

Figure 7. Status of law and regulations concerning public funds in Bangladesh.

Note: $1=$ Clear and well understood (10\%), 2= Clear but not well understood by stakeholders $(35 \%)$, $3=$ Not very clear $(19 \%), 4=$ Not familiar with those laws and regulations $(36 \%)$ 


\section{Nature of existing public accounting systems}

The study showed that the highest numbers of people (37\%) did not have any idea about the existing public accounting systems relevant to making the REDD+ program transparent and predictable in Bangladesh. Important five components of the public accounting system were shared with the respondents. These were source documents, input devices, information processes, information storage, and output devices. A few numbers of respondents (9\%) thought that the then public accounting systems were very transparent, reliable and predictable. About $29 \%$ of people thought that it was somewhat transparent, predictable and reliable, but about $25 \%$ of people thought, it was not transparent, reliable or predictable at all (Figure $8)$.

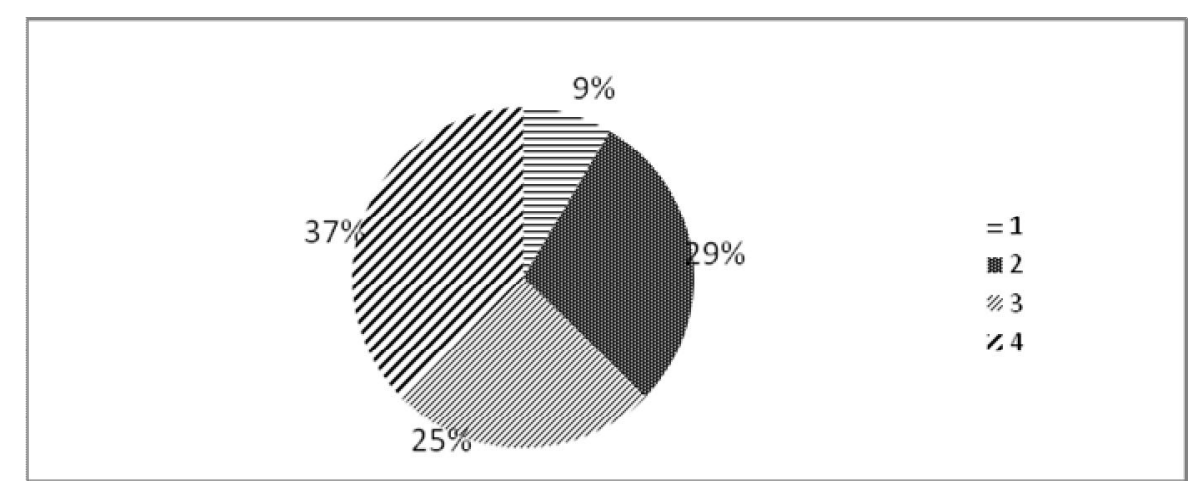

Figure 8. Nature of existing public accounting systems in Bangladesh.

Note: $1=$ very transparent, reliable and predictable $(9 \%), 2=$ somewhat transparent, predictable and reliable $(29 \%), 3=$ Not transparent, reliable or predictable at all $(25 \%), 4=$ no idea $(37 \%)$ 
The respondents of Rangamati, Madhupur, and Sreemangal (FGD and KII) were not aware of the nature of existing public accounting systems. It has been confirmed that when the public accounting system is not transparent, reliable and predictable due to inefficient civil service and low bureaucratic quality, it facilitates the official to involve in corruption $[6,35,39,40]$. In 2007 , the public sector accounting and auditing of Bangladesh were compared with the international standards by the World Bank. It suggested improving the public sector accounting and auditing of Bangladesh to the international standard [40].

\section{The efficiency of organizations managing REDD+ in Bangladesh}

The internal control and external auditing in fiscal spending of organization managing REDD+ in Bangladesh are to be transparent and reliable. Most of the respondents (36\%) thought that there were some insufficient efforts to internal control and external auditing. It is to be noted that the Forest Department in Bangladesh is the main agent to implement the REDD+ in Bangladesh. About 13\% said it was poor to control and audit while only $3 \%$ thought it was effective in specific cases (Figure 9).

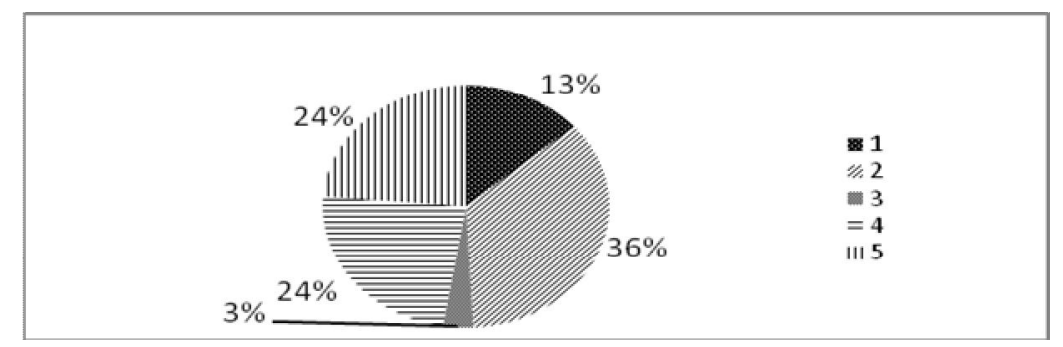

Figure 9. The effectiveness of fiscal spending in the organizations managing REDD+ in Bangladesh.

Note: $1=$ poor $(13 \%), 2=$ there are some efforts, but they are insufficient $(36 \%), 3=$ effectively $(3 \%)$, $4=$ it depends on the organization $(24 \%), 5=$ no idea $(24 \%)$ 
Comparing the efficiency parameter of fiscal spending in organization managing REDD+, the study found that there were some efforts of internal controls and external auditing to the fiscal spending but they were insufficient because of the inefficiency and low bureaucratic quality of the forest department. The reality is that there is a lack of transparency and accountability in the public accounting and auditing which enhances the corruption in the public offices $[6,35,39,40]$.

A study in Indonesia shows that regional politicians, government officials, and businessmen are involved in corruption by using their discretion over the budgetary allocations, contracts at the center of government and other assets at their disposal [41].

\section{Procurement policies in the Forest Department}

About $31 \%$ respondents had no any idea about procurement policies in the forest department because of no access of people to the annual report of forest department while $30 \%$ people thought there were no any transparent and overseen independent institutions to check the procurement policies in the forest department. About 29\% of people thought that the procurement policies were somewhat transparent and reliable and only 10\% thought it was highly transparent (Figure 10). They thought the auditing system could check out the procurement policies in a normative way to confirm the procurement transparent and reliable. Although they thought the public access to procurement activities was not guaranteed. 


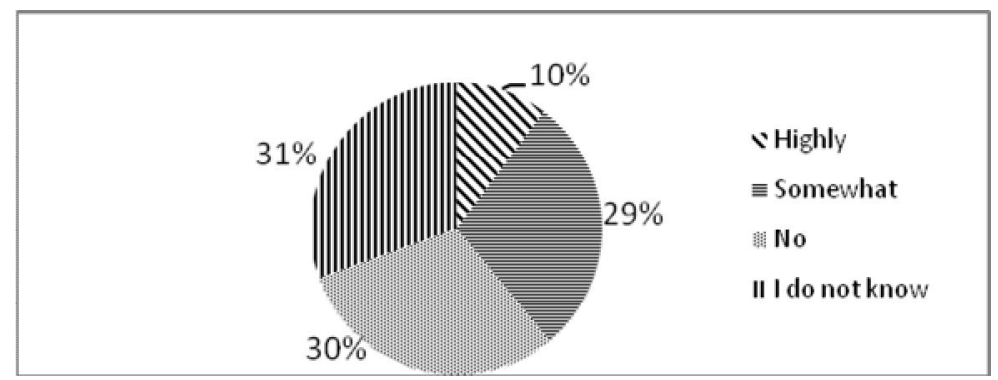

Figure 10. Observational status of procurement policies in the forest department of Bangladesh.

There is a corruption risk in procurement. Large, capital intensive and complex projects and corrupt practices occur in the form of inadequate advertising, short biding times and taking bribes from bidders by leaking the information [42].

\section{Accessibility to the general public on information of Forest Department}

About $12 \%$ of respondents thought that the forest department provided highly accessibility to the general public on information on procurement plans, procurement policies, and contract awards. Maximum respondents (37\%) thought that their accessibility in the forest department was moderate for getting information on procurement plans, policies and contract awards. About 22\% had no idea about procurement plans, policies of forest department and $29 \%$ thought that they had no access to information of forest department (Figure 11). 
166 Contextualization of Forest Governance for Implementation of REDD+ in Bangladesh

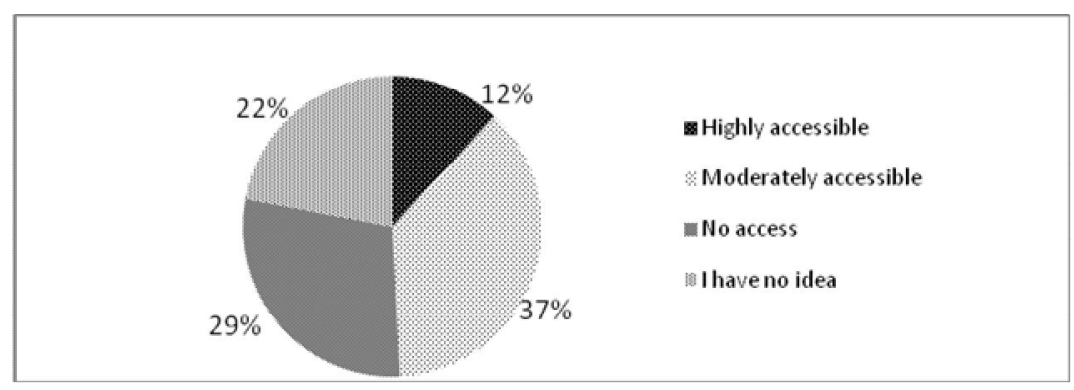

Figure 11. Accessibility to the general public on information on the Forest Department of Bangladesh.

About $81 \%$ ofrespondentsdid not have any idea to request information about budgets, expenditures, employment opportunities, procurements in the forest department for REDD+ program. Only 19\% thought they know where to have to request for information. The comparison shows the poor information exchange scenario in forest department (Figure 12).

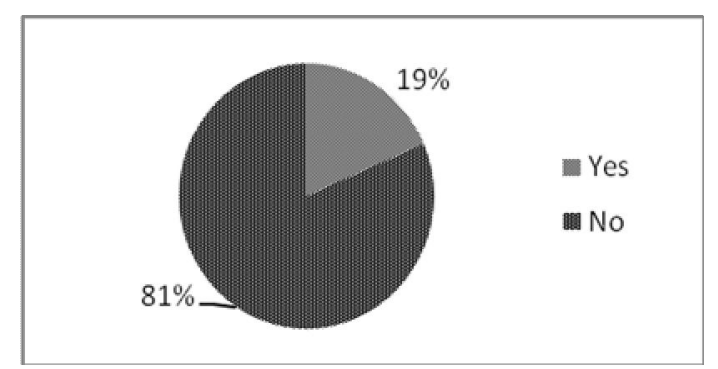

Figure 12. Knowledge about the source of information on corruption in Bangladesh. 


\section{Existing mechanisms to feedback, grievance, and redress in the Forest Department}

The highest number of respondents $(62 \%)$ thought that the present mechanisms for demanding accountability were slow and about 55\% thought that it was biased while about $53 \%$ and $47 \%$ thought that the process was ineffective and unpredictable, respectively (Figure 13). The respondents thought that the mechanisms were timely, predictable, equitable, impartial and opaque in respect to the existing mechanisms to feedback, grievance, conflict resolution, and redress were $8.6 \%, 3.4 \%, 3.4 \%, 5.2 \%$, and $24.1 \%$, respectively.

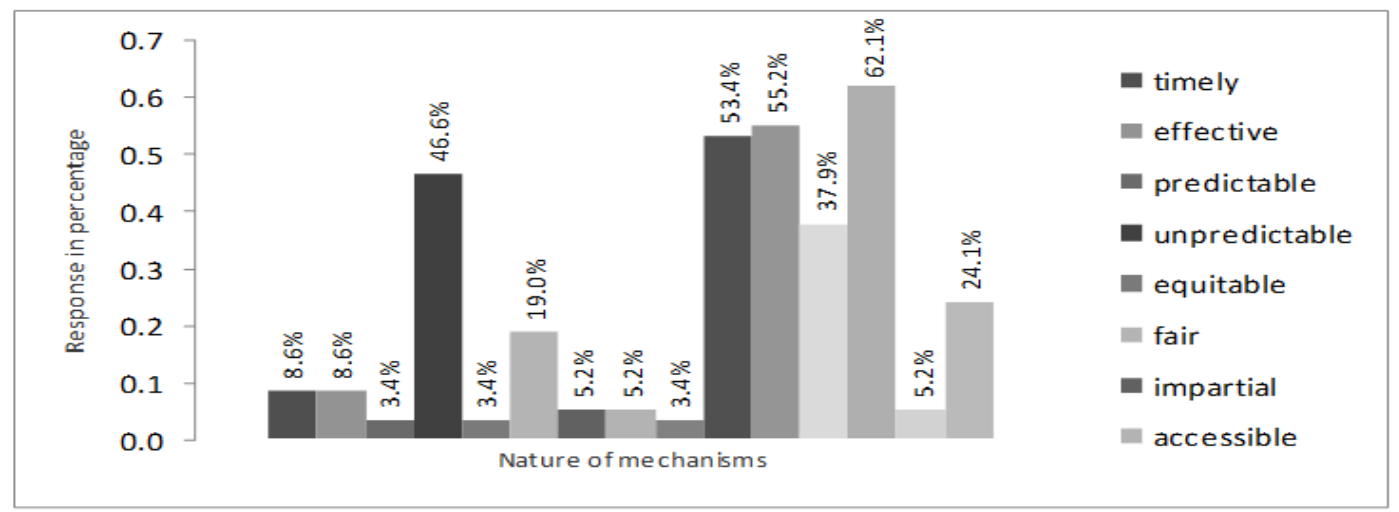

Figure 13. Existing mechanisms for feedback, grievance, and redress in the forest department of Bangladesh.

It was found that people were interested to complain, a local politician, headman, religious leaders for grievance and redress due to the absence of updated mechanisms of resolution of forest-related activities in the forest department. It is necessary to ensure independent grievance and redress mechanisms at national levels to reduce conflicts among stakeholders and the adverse impacts of REDD+. 
This update also ensures the accountability of donors and REDD+ implementers under the legal framework of human rights, and environmental and social integrity $[6,35,43]$.

\section{Complaints mechanisms to all stakeholders}

The accessibility of complaints mechanisms varies from stakeholders to stakeholders on the basis of literacy, abilities and ethnic groups or peoples of using different languages. About 55\% of respondents thought present complaints mechanisms are not accessible to all stakeholders and only 14\% respondents thought it was accessible. On the other hand, $31 \%$ of respondents did not have any idea about complaints mechanisms (Figure 14).

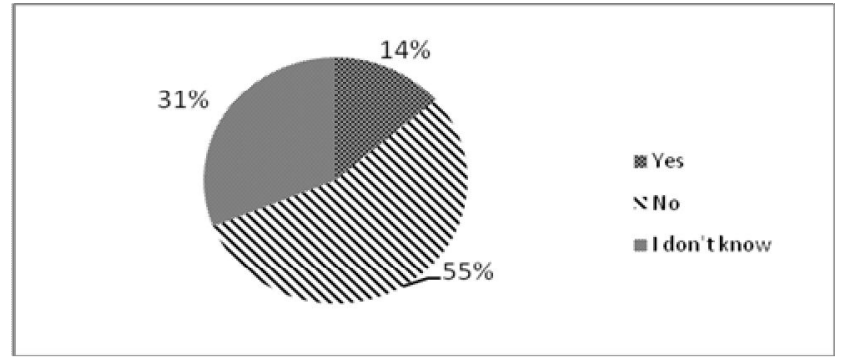

Figure 14. The effectiveness of complaints mechanisms to all stakeholders in Bangladesh.

At Rangamati, Madhupur, and Sreemangal, it showed that there was no effective complaints mechanism accessible to all stakeholders but people complained to local political leaders, religious leaders and rarely to higher forest officials. But complaints mechanisms are important to resolve as early as the risks and concerns of REDD+ rose due to the insufficient participation, consultation and equitable benefits sharing and land tenure. 
An independent, effective and accessible resource and complaints mechanism is a vital part of managing corruption risk and the absence of this mechanism facilitate the continuous unchecked, unchallenged illegal corruption activities in public offices. Accessibility of indigenous people and local communities should be ensured for effective recourse and complaints mechanisms with respect to literacy, abilities and different languages [42].

\section{Perception of whistleblower protection act}

The study shows that about $55 \%$ of respondents did not have any idea about whistleblower protection Act. The $33 \%$ of people thought that the act doesn't give any confidence to report corruption crimes while only $12 \%$ of peoples' perception as that it gives the confidence to report against corruption crimes (Figure 15). Bangladesh enacted 'Public interest related information discloser (Protection) Act, 2011 as a Whistleblower protection Act to disclose the information on activities against public health, security and environment,and illegal and criminal activities alongside embezzlement of public money, properties and misuse of power and irregularities in any organization.

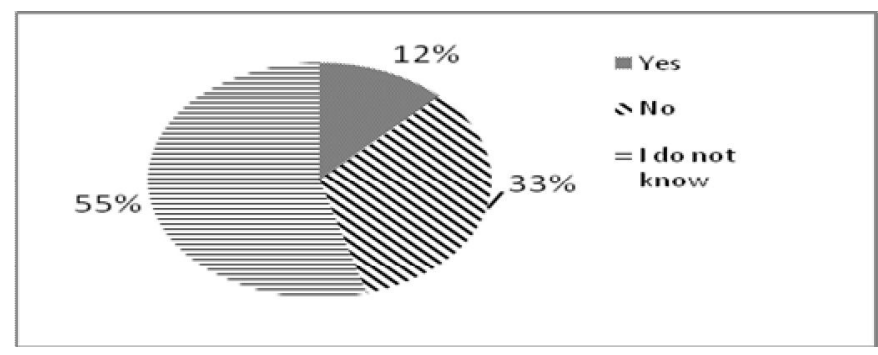

Figure 15. Perception of the respondents on whistleblower protection Act, 2011 in Bangladesh. 
India also enacted whistleblower protection Act, 2011 to ensure public interest on information disclosure [44]. But according to BSS (Bangladesh Sangbad Sangstha) less than 10 percent mid-class government officials know the whistle blower Act on graft practices, public interest violation, and protection of information providers.

\section{Current practices to deter/discourage in corrupt activities}

In Bangladesh, there are some practices for detection, investigation, and prosecution to deter/discourage the people who involved in corrupt activities. The main question about these practices is effectiveness. The study finds that prosecution practice is in the highest rating (2.64) which means that it is highly effective if it is properly implemented. The rating of investigation practice is 2.45 and the detection's rating is 2.43 which mean that the practices of detection and investigation should be reformed and improved (Figure 16).

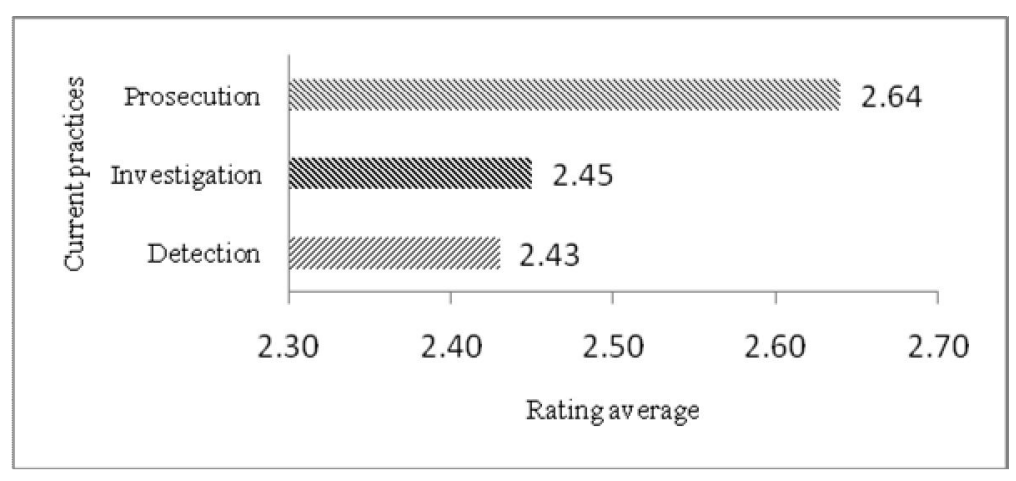

Figure 16. Current practices to deter/discourage in corrupt activities in Bangladesh. 
It shows that there were no practices to discourage the people who tempted to involve corrupt activities but there were some encouraging factors to involve corrupt activities.

\section{Programs and institutions for stakeholders' justice}

There are some programs and institutions in Bangladesh that ensure access to justice for stakeholders. These are legal protection, legal awareness, legal aid and counsel, adjudication, enforcement, civil society oversight, parliamentary oversight, etc. In an online survey, among these programs and institutions, legal protection has the highest rating 2.19 which means that legal protection has the highly likely to ensure access to justice for stakeholders. On the other ratings, the point of legal awareness, legal aid, and counsel, adjudication, enforcement, civil society oversight, parliamentary oversight are 1.57, 1.47,1.29, 1.68, 1.79 and 1.35, respectively. The lowest rating (1.29) is of adjudication which means that there is a lack of proper implementation of the law (Figure 17).

At Madhupur, it was found that civil society played a vital role by protecting the illegal forest activities and along this print media, BELA (Bangladesh Environmental Lawyers Association), Law center and TIB (Transparency International, Bangladesh) office worked actively creating pressures to forest officials. 
172 Contextualization of Forest Governance for Implementation of REDD+ in Bangladesh

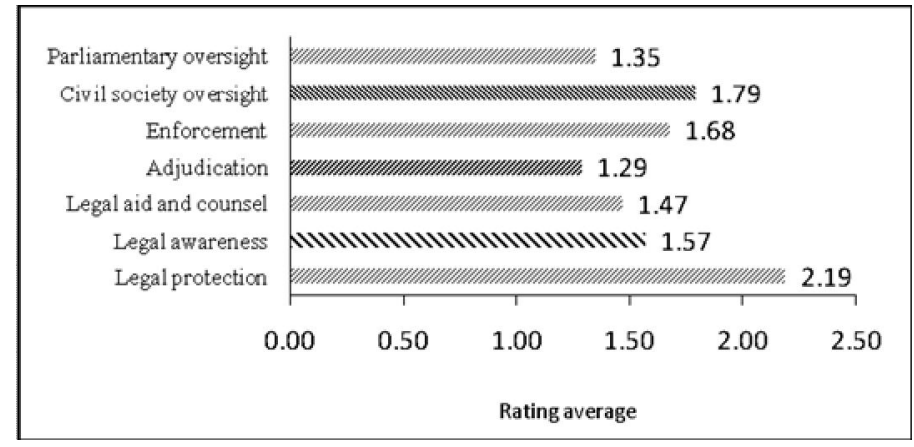

Figure 17. Programs and institutions to ensure access to justice for stakeholders in Bangladesh.

The legal protection, civil society oversight, and law enforcement etc. play a vital role to ensure the access to justice for stakeholders. The strong role of civil societies is the sign of good governance in a state and it ensures accountability of state and freedoms of the citizen. Strong civil society ensures the rule of law and human rights with respect to diverse ethnic, religious, cultural and racial identities [45]. But the weak role of civil society makes the state unstable, in Tajikistan due to the strong rule of civil society. They overcame the political problems of the civil war in 1997 through improving political accountability [46].

There are different types of civil society such as charities, social, voluntary or community institutions, social enterprises or other nonprofit organizations. They can be effective in helping hands for the government for providing better insights into demand for and suitable means of public services delivery. 


\section{Conclusions}

The study revealed that lack of transparency, accountability, and integrity are the main underlying drivers of deforestation and forest degradation in Bangladesh because of the low accountability and discretionary powers, the source of illegal logging and extortion of bribes in the forestry sector. Restriction to accessing reports on fiscal activities, lack of laws and regulation concerning to public funds, lack of independent institution, ineffective monitoring and testing systems, and inadequate detection, investigation and prosecution practices, etc., are the sign of weak governance systems in forestry sector that facilitate the forest officials to involve themselves in corrupt activities in Bangladesh. Poor governance systems also decrease the possibilities of getting revenue from donor country through REDD+ in Bangladesh. To improve the governance system in forestry sector needs to legal action against corruption, engage civil society to ensure the accessibility of all stakeholders in all spheres of organizational structure and to the structural change of forest department in Bangladesh.

\section{Acknowledgment}

The study was supported by UNDP, Dhaka, Bangladesh.

\section{References}

[1] T. Marmon: "Corruption in the forestry sector and illegal logging: The problem, its implications and approaches to combating it", German Technical Cooperation (GTZ), Eschborn, Germany, 2009, p. 15. 
174 Contextualization of Forest Governance for Implementation of REDD+ in Bangladesh

[2] WB (The World Bank): "Combating illegal logging and corruption in the forestry sector", The World Bank, Washington, D.C. 2006, p. 4.

[3] M. R. Guariguata and P. Balvanera: Forest Ecology and Management, 2009, 258 (9), 1825.

[4] FAO (Food and Agriculture Organization): "Global forest resources assessment 2010: Main report", Food and Agriculture Organization (FAO), Rome, Italy, 2010, p. 343.

[5] A. E. Sarker: International Public Management Journal, 2004, 7(3), 365.

[6] TIB (Transparency International Bangladesh): "Transparency and accountability in forest conservation and management: Problems and way out", Transparency International, Dhaka, 2008, p. 73.

[7] IPCC (Intergovernmental Panel on Climate Change): "Climate change 2007: Synthesis report", Cambridge University Press, Cambride, UK and New York, USA, 2007, p. 112.

[8] UNFCCC (United Nations Framework Convention on Climate Change): "Copenhagen accord. FCCC/CP/2009/L.7", United Nations Framework Convention on Climate Change (UNFCCC], Bonn, Germany, 2009, p. 5.

[9] K. Evans, L. Murphy and W. D. Jong: Environmental Science and Policy, 2014, 35, 98.

[10] A. Thorpe and L. Ogle: "Staying on track-tackling corruption risks in climate change", United Nations Development Program (UNDP), New York, USA, 2010 , p. 76. 
[11] A. Angelsen, S. Brown, C. Loisel, et al.: "Reducing emissions from deforestation and forest degradation: An options assessment report", Meridian Institute, Norway, 2009, p. 116.

[12] G. Ludwig: Transnational Environmental Law, 2012, 1(02), 381.

[13] D. Melick: Conservation Biology, 2010, 24(2), 359.

[14] J. Graham, B. Amos and T. Plumptre: "Principles for good governance in the 21st Century", Ottawa, 2003, p. 15.

[15] UN-REDD (United Nations REDD): "UN-REDD Bangladesh national programme ", Dhaka, 2019, p. 2.

[16] UN-REDD (United Nations REDD): "National program submission form Bangladesh", Geneva, 2013, p. 11.

[17] A. M. Larson and J. C. Ribot: Lessons from forestry decentralisation, in: A. Angelsen (Ed.) "Realising REDD+: National strategy and policy options", The Center for International Forestry Research (CIFOR), Bogor, Indonesia, 2009, p. 175.

[18] P. C. Motel, R. Pirard and J. L. Combes: Ecological Economics, 2009, 68(3), 680.

[19] C. M. Barr and J. A. Sayer: Biological Conservation, 2016, 154, 9.

[20] G. Paoli, P. Wells, E. Meijaard, et al.: Carbon Balance and Management, 2010, 5(1), 7.

[21] P. H. Raven: Our diminishing tropical forests, in: E.O. Wilson (Ed.) "Biodiversity", National Academy Press, Washington, 1988, p. 119.

[22] B. B. N. Strassburg, A. Kelly, A. Balmford, et al.: Conservation Letters, 2010, 3, 98. 
176 Contextualization of Forest Governance for Implementation of REDD+ in Bangladesh

[23] J. Busch: Conservation Letters, 2011, 4(2), 101.

[24] T. A. Gardner: Biological Conservation, 2011, 154, 61.

[25] L. Gibson: Nature, 2011, 478(7369), 378.

[26] C. A. Harvey: Conservation Letters, 2010, 3(1), 53.

[27] W. Cavendish: World Development, 2009, 28(11), 1979.

[28] P. Kamanga: Ecological Economics, 2009, 68(3), 613.

[29] M. Pouliot: Ambio, 2016, 41(7), 738.

[30] C. M. Shackleton: Building a holistic picture: An integrative analysis of current and future prospects for non-timber forest products in a changing world, in: C.M. Shackleton, S.E. Shackleton, P. Shanley (Eds.), "Non-timber forest products in the global context", Springer, Berlin, 2011, p. 255.

[31] A. Whiteman and A. Lebedys: International Forestry Review, 2006, 8(1), 31.

[32] M. S. H. Chowdhury and M. D. Miah: Journal of Forestry Research, 2003, 14(3), 253.

[33] S. Dewi: World Development, 2005, 33(9), 1419.

[34] Anonymous: Survey Monkey, California, USA. 2018.

[35] TI (Transparency International): "Keeping REDD+ clean: A step-by-step guide to preventing corruption", Transparency International (TI), London, 2012 .

[36] M. A. Salam, T. Noguchi and M. Koike: Geojournal, 1999, 47(4), 539.

[37] M. E. Margulis: Land grabing and global governance: Some initial observations, International conference on global land grabbing II, Ithica, Department of Development Sociology, Cornell University, 2012, p. 17. 
[38] M. S. Iftekhar and A. K. F. Hoque: Geojournal, 2005, 62(1-2), 95.

[39] M. Ehsan: Asian Affairs, 2008, 151(1), 41.

[40] WB (The World Bank): "Bangladesh public sector accounting and auditing: A comparison to international standard", The World Bank, Dhaka, Bangladesh, 2007, p. 82.

[41] C. Palmer: World Economics, 2005, 6(2), 1.

[42] R. Ahammad, M. K. Hossain and P. Husnain: Journal of Forestry Research, 2014, 25(1), 29.

[43] TI (Transparency International): "Global corruption report: Climate change", Earthscan, London, UK, 2011.

[44] D. Mangala and P. Kumari: Journal of Commerce \& Accounting Research, $2015,4(1), 35$.

[45] U. Uprety: The International Journal of Not-for-Profit Law, 2011, 13(3), 50.

[46] I. Zharkevich: "The role of civil society in promoting political accountability in fragile states: The case of Tajikistan", International NGO Training and Research Centre (INTRAC), Oxford, UK, 2010, p. 53.

Manuscript received on 03 August,2016, Revised manuscript received on 28 April, 2019 and accepted on 29 April, 2019

The Chittagong Univ. J. Sc. Vol. 41(1), 2019 